\title{
e-Learning quality: Scale development and validation in Indian context
}

\author{
Arun Kumar Agariya*
}

Department of Management Studies

ABV-Indian Institute of Information Technology and Management, India

E-mail: arunagariya@gmail.com

\section{Deepali Singh}

Department of Management Studies

ABV-Indian Institute of Information Technology and Management, India E-mail: drdeepali@iiitm.ac.in

*Corresponding author

\begin{abstract}
The aim of this paper is to develop a reliable and valid e-learning quality measurement scales from the learner as well as faculty perspectives in Indian context. Exploratory factor analysis followed by confirmatory factor analysis was done which is presented in two forms; covariance model and the structural model. The covariance model shows that the factors namely collaboration, industry acceptance and value addition are important from the learner's point of view whereas the factors namely transparency in assessment, technical know-how and engagement (from students) are important from faculty point of view. Factors namely course content and design structures (technology/website design) are found equally important for learner's as well as faculty's perspective. The structural models validate the previously extracted factors along with their indicators. The findings of this study validate the long held belief that e-learning quality is a multidimensional construct and serves as a critical success factor. The proposed scale will help in identifying issues that contribute towards e-learning quality in Indian context and thereby formulating strategies accordingly, resulting in efficient (in terms of cost) and effective (outcomes) e-learning practices, which is the necessity of the hour for the economic development of the country. A fair amount of literature on e-learning dealt with identifying factors explaining the constructs of quality, perceived value and satisfaction. But there is paucity of research pertaining to e-learning quality scale development and validation from the learner as well as faculty perspective. This study is an attempt to bridge this gap in the existing literature.
\end{abstract}

Keywords: e-Learning quality scale; Exploratory factor analysis; Confirmatory factor analysis; Structural equation modeling; India

Biographical notes: Arun Kumar Agariya is a doctoral student at ABV-Indian Institute of Information Technology and Management, Gwalior. He has an industrial experience of two years in financial services sector. His research interest includes Relationship marketing, e-learning \& advertising and sales management.

Deepali Singh is a Professor of the ABV-Indian Institute of Information Technology and Management, Gwalior. She has been a university top rank in MBA (1994) and completed Ph.D. in the area of Management in 1999. She has 


\begin{abstract}
been teaching nearly 16 years at PG level (Post Ph.D. 12 years and Pre-Ph.D. 4 years experience). She is Gold-medalist UGC-NET qualified, Accredited Management Teacher and merit holder throughout her academic career. She has been very active in research in the area of Marketing for over 16 years. She has guided many Ph.D. students and PG Students (MBA, M Tech) in new and innovative areas of e-Marketing, e-CRM, Ethical Brand Positioning; IT enabled Distribution Systems, Neuro- Marketing, Customer Centric New Product Development, Customer Perceived value, Services Quality framework for Telecom Services, Supplier Relationship Management, e-Retail etc.
\end{abstract}

\title{
1. Introduction
}

Let's have a peek into a near future, which is getting as real as possible with launch of latest technology and its integration.

Imagine the events of a regular student in a near future, he wake up in the morning and receives the day's schedule of lecture on his latest smart phone, with details about the topics to be discussed in the lecturers. He then uses his Apple I-pad to Google those topics to get an overview, update about the same on the facebook as his latest status. His friends (batchmates) give their opinion as comments and they have a pre-class discussion about the topic.

The description of similar kind of situation can be found in the work of various esteemed authors (Anderson \& Elloumi, 2004; Cashion \& Palmieri, 2002; Ehlers, 2009). The technology is evolving at a rapid pace than even before and its application to education has made dramatic changes in the educational field. Few years back this would have been a starting point of a sci-fi story but with advancement of technology and introduction of the same to the universities, this is not just imagination but a description of near future. Internet is provided free (or at nominal cost) in all the major universities and technical institutions. Thus it is high time to use this facility in the constructive manner as it is widely found that still the internet is not used at its best and its use is limited to downloading irrelevant material and surfing websites that do not contribute to the core idea of providing knowledge.

This has necessitated the concept of e-learning. E-learning has been defined as "pedagogy empowered by digital technology" (Nichols, 2008). E-learning can also be defined as technology-based learning in which learning materials are delivered electronically to remote learners via a computer network (Zhang, Zhao, Zhou, \& Nunamaker, 2004). The term is also utilized to refer out-of-classroom and in-classroom educational experiences via technology, even as advances continue in regard to devices and curriculum (Tavangarian, Leypold, Nolting, Roser, \& Voigt, 2004). Learning is no longer confined with boundaries, neither in terms of place nor time (Ehlers, 2009). Elearning industry came into focus and attracted a lot of investments in late 1990's. From $2000-2008$, the e-learning industry grew ten-fold globally and achieved a stimulating growth of 35.6\% (Suna, Tsaib, Fingerc, Chend, \& Yeha, 2008). The Indian market has been slow in adapting to e-learning and the expected annual growth rate of the Indian elearning market is $20-25 \%$. The exponential development in the internet and multimedia technologies are the major enablers for it with content, technologies and services being identified as the three key sectors of the e-learning industry (Nagy, 2005). E-learning in India is quite popular among the professionals who have joined the workforce early for 
them it is a means to complete their education without much hassles from the repudiated institutes which will be quite helpful in their career progression.

e-Learning can be classified in four types as Individualized self-paced e-learning online, Individualized self-paced e-learning offline, Group-based e-learning synchronously and Group-based e-learning asynchronously (Naidu, 2006). There are a number of benefits from e-learning like interactivity, anytime, anywhere and anyone flexibility, portability, higher retention, greater collaboration, reduced overall cost, consistency in delivery, expert knowledge etc. But still it can't be consider as a completely successful endeavor as failures do exist. Despite of various attempts made by industry as well as academicians, little information is available regarding why many users do not continue their online learning after their initial experience and what best can be done to provide a quality course material that is able to meet the expectations of the user. Although India is well equipped with the infrastructure required for e-learning, still it has a long way to go in terms of creating a platform to profile all universities in India. No doubt that e-learning can play a very significant role in developing countries like India, in terms of facilitating education for all. The infrastructure require for an online university would be much smaller than that of a real university but main concern would be the acceptability from industry and society. Let us take the example of Indira Gandhi Open University, New Delhi (IGNOU), established in 1985 is promoted as people's university. It has affiliation from all the major Institutions like UGC, AICTE, and DEC etc. Academic staff (of only 325 in numbers) is able to impart education to more than 3.5 million users in 2010. Employability is the major concern for these students.

Hence it is clear that the scope of online education in India is actually much wider but this area is largely untapped, and there is ample scope for improvement. The availability of huge number of student base is one of the major advantages in India. The general trend in India and other developing countries is that the repudiated universities and institutions are clustered in the big cities mainly in metros. Thus it's the compulsion for the small town students to leave their home town and come to these big cities and thus bear the costs e.g. lodging and boarding costs apart from the cost of education. E-learning can play a major role in bridging this gap. It can facilitate these small town students to get education at their native place. Apart from proper course works, some E-learning portals (largely private) in India are also providing various learning opportunities to the techsavvy students, like conducting mock tests for various competitive examinations like engineering, medical and management, e.g. the Indiatimes group has introduced the Mindscape test centre where one can appear for mock IIT-JEE exams online for making self-assessment.

NIIT and TATA interactive systems are pioneers in the industry. But the steady growth in the E-learning market has attracted IT companies, KPOs, BPOs, and publishing houses such as Element K, McGraw-Hill, Lionbridge, Skillsoft, IBM, and Oracle. These global companies have set up E-learning centres all across India. As is the case of Indian scenario, despite having a huge base of students and a need of well established e-learning model, the existing e-learning services are far from satisfactory. Still the use of this alternative form of education is very limited and the lecturers are continuing with traditional form of teaching. Through this study, an attempt is made to bridge this gap and develop quality measurement scales specifically catering to India to facilitate quality learning in the online environment and facilitating e-learning industry to grow at a much faster pace than even before. 


\section{Literature review}

Technological advances are dramatically altering the training and development landscape in India. Although the adoption of online learning programs by Indian organizations has been significant (Mittal, 2008), a concern amongst practitioners in the field of e-learning about the issue of quality has grown in recent years (McLoughlin \& Visser, 2003; Oliver, 2005). The concern about quality in e-learning has also grown amongst education and training providers and national accreditation and quality agencies (Quality Assurance Agency, 2004; Western Cooperative for Educational Telecommunication, 2002). Several research studies have explored the issues related to web site which are affecting learners while interacting with the e-learning websites. Since multimedia materials are heavily used in e-learning systems, a high-bandwidth network is a basic requirement for efficient content access (Zhang et al., 2004). So the organizations involved in providing online education should consider the factors that are affecting learner's satisfaction with their websites and should prepare strategies to effectively deal with such factors.

Service quality involves a comparison of expectations with performance. Service quality is a measure of how well a delivered service matches the customers' expectations (Lewis \& Booms, 1983). Thus we can define it as the discrepancy between consumer's perceptions of services offered by a particular service provider and their expectations about the offered services (Aagja \& Garg, 2010; Ganguli \& Roy, 2011; McKinnon, Walker, \& Davis, 2000; Newton, 2007; Phipps \& Merisotis, 2000; Sims, Dobbs, \& Hand, 2002; Suddaby \& Milne, 2008). E-learning service quality is the discrepancy between students (or learners) experience with the services (course material including curriculum design, e-learning functions, etc) offered by a particular institution and their expectations about services. Quality has always been a prime concern in education field and hence numerous studies related to quality and education has been conducted all across the world. In general most of the research studies concluded that the campus based universities need to reassess their respective approach to the quality assurance / quality enhancement of elearning courses (Boettcher \& Conrad, 1999; Jara \& Meller, 2009). Previous researchers have tried to identify and suggest various frameworks (Bridgland \& Goodacre, 2005; Inglis, 2005) that can be used in assessing the standard of the e-learning courses.

Inglis (2008) identified some methods of validation that have been used in relation to development of different frameworks, and four main types of quality processes that are used in developing a quality framework for e-learning education namely Quality Assessment, Benchmarking, Quality and Quality improvement. Also, since the quality is a relative term it is not feasible to have a single global measure that will suit all conditions. Much effort has been placed in arriving at this single global measure and none has been conclusive (Inglis, 2005).

Another study describes the features of a new framework and explains how to develop the e-learning design skills of academic staff and to encourage greater engagement with e-learning quality initiatives across the university (Ireland, Correia, \& Griffin, 2009). The study suggests basic and advanced standards of e-learning. Another researcher has gone one step further by discussing about next generation of e-learning as next version web surfaces with more media content. This generation is called as Elearning 2.0, as it heavily uses the features of web 2.0 (Ehlers, 2009). Institutions and organizations that offer the e-learning contents have always felt the need to have a well set framework to measure the quality of e-learning. This leads to identifying measures on which these frameworks would be based. Various attempts have been made to identify and standardize quality measures by many organizations, research institutions and individuals to ensure quality and assurance in e-learning (Cho \& Lee, 2004; Chua \& Lam, 
2007; Doherty, 2008; McLoughlin \& Visser, 2003). In another study e-learning needs assessment model containing eight components is proposed to assess an e-learning organization's readiness (Chapnick, 2000). The study (Segrave, Holt, \& Farmer, 2005) outlined components summarizing organization's sustainability. In another study conducted by the Economist Intelligent Unit in the year 2003, to assess the e-learning readiness of a country, nearly 150 qualitative and quantitative criteria were identified. The identified criteria were further classified into four categories, i.e. Capability, Content, Connectivity and Culture referred as 4Cs (Chen, 2009). Authors have also suggested few measures to improve the capacities for effective online teaching and learning, and hence improving overall quality of e-learning content. They have argued that a systamatic and strategic based approach for overall academic professional development (APD) is a need of hour. A much similar study was conducted recently by the authors (Jung, 2010) where the author analysed dimensions of e-learning quality, from the learner's perspective. Seven dimensions were identified in evaluating the e-learning quality: Interaction, Staff Support, Institutional Quality Assurance Mechanism, Institutional Credibility, Learner Support, Information and Publicity and Learning Tasks.

Similar kind of studies was undertaken by other eminent authors (Dolog, Henze, Nejdl, \& Sintek, 2004; Dondi, Moretti, \& Nascimbeni, 2006; Finch, 2006; Frydenberg, 2002; Little \& Duffy, 2011; Agariya \& Singh, 2011a, 2011b, 2012; Silius et al., 2010; Nakabayashi, Morimoto, \& Hada, 2010; Ge, Lubin, \& Zhang, 2010) but there is paucity of research done in Indian context. Inglis, 2008 has pointed out that generalizability of the studies is the main issue because of the major limitation of geographical areas in which the studies performed. E-learning in India is gaining importance but at a slower pace. Indian market has emerged as an attractive destination for e-learning service provider due to the fact that more than half of the Indian population is below the age of 25 years and the number of internet users are growing rapidly, which clearly indicates the need to develop a quality measurement scale for enhancement and value addition in elearning. Various authors have suggested that the main limitation of their respective study is that the result depends hugely upon the framework taken and the audience. In case of Indian scenario, e-learning is yet to evolve in its fullest manner. Although a few educational institutions and some websites do provide e-learning facility still most of these are in a distance learning mode and also provide material in paper form, which is preferred more by the learners as well as institutions themselves e.g. IGNOU. Another example in case of e-learning is NIIT Imperia, which has collaborated with some of the major management institution of India like IIM's, IMT-Ghaziabad, IIFT-New Delhi, MDI Gurgaon etc. to provide various certification courses in management for corporate employees in conventional classroom education coupled with advanced e-learning techniques. The objective of this research work are to study existing quality framework and identify a number of factors on the basis of which the quality of E-learning can be measured and to propose the measurement scales for ensuring quality in e-learning development and delivery.

\section{Research methodology}

For this study, we initially developed 65 scale items for identifying e-learning constructs from relevant literature review; this was followed by depth interviews with the students and faculty members of different institutes and universities all across India. A total of 21 students and 15 faculty members were interviewed for major issues that exist while elearning, this resulted in pruning and fine tuning the items. In the subsequent questionnaire survey a total of 414 and 310 responses were received from the students 
and faculty members respectively. The exploratory factor analysis is performed with the first half of the data (207 and 155) to identify the major e-learning quality dimensions based on which authors have proposed the constructs from both the perspectives, which were confirmed through confirmatory factor analysis and validated through Structural equation modelling by using the other half(207 and 155) of the data.

\subsection{Depth interview}

Depth Interview was conducted of length with 21 students and 15 faculties of different institutes and universities all across India. The duration of depth interview varied anywhere between 15 to 20 minutes. A list containing 65 dimensions extracted from the literature review is given to interviewee along with a brief description of each dimension. Based on the results of the depth interview the questionnaires were modified.

\subsection{Key findings of depth interview}

The initial list of 65 dimensions collected from literature review was further reduced to 42 and 44 after the depth interviews from learner and faculty perspectives respectively. Findings of depth interview shows, $90 \%$ of the respondents were aware of e-learning. The main facilities they were availing from the e-learning websites are downloading course material, pursuing online certification course, participating in various quizzes, taking guidance from the faculty members through online chat forum etc. The major issues identified from learner perspectives were related to course structure, design structure, industry acceptance whereas in addition to these transparency in assessment and engagement from the students are the major issues identified from faculty perspective.

\subsection{Questionnaire survey}

The modified questionnaires are based on these 42 and 44 dimensions from the learners and faculty perspectives followed by a pilot survey of the questionnaire to assess the content validity. Content validity can be evaluated by a panel of persons, sometimes experts, who judge whether a scale logically appears to accurately reflect what it purports to measure (Zikmund, 1991).

From the result of the pilot survey 12 dimensions from the learner's perspective and 16 dimensions from faculty perspective are removed. As a result, the revised questionnaires contained 30 dimensions from learner's perspective and 28 dimensions from the faculty member's perspective (survey items). The revised questionnaires structure comprises of:

Questionnaire 1: From learner's perspective (30 survey items).

Questionnaire 2: From faculty perspective (28 survey items)

Section-1: Demographic information of the respondents and

Section-2: Items measuring the respondent's perceptions on specific characteristics of e-learning services and overall e-learning quality.

The respondents were requested to select the response that best indicates their experiences or perceptions on each statement, using a five point Likert-scale (From 1= strongly disagree to $5=$ strongly agree). 


\subsection{Key results of questionnaire survey}

Responses to the revised questionnaires were received through online as well as offline from the respondents all across India. The respondents of this study were students and faculty members of different institutes and universities all across India. A total of 414 and 310 responses were received for questionnaire- 1 and 2 respectively. Furthermore the reliability analysis, sampling adequacy analysis and exploratory factor analysis was carried out with the first half of the data (Sample size: 207 and 155) to identify the major constructs, subsequently confirmatory factor analysis was carried out with the second half of the data (Sample size: 207 and 155) to confirm the factor structure as well as to provide evidence of scale reliability, dimensionality and validity and finally the structural equation modelling was carried out to validate the results. SPSS-15 and AMOS-7 software were used for carrying out statistical analysis mentioned above. The demographic profile of the respondents is given in Table 1.

\section{Table 1}

Demographic profile of the respondents

\begin{tabular}{lllll}
\hline S. No. & Demographic Criteria & & Learner (\%) & Faculty (\%) \\
\hline $\mathbf{1}$ & Gender & Make & 64.49 & 66.13 \\
& & Female & 35.51 & 33.87 \\
\hline $\mathbf{2}$ & Age & Between 18-30 years & 71.74 & 34.52 \\
& & Between 30-45 years & 26.09 & 34.19 \\
& & Above 45 year & 2.17 & 31.29 \\
\hline $\mathbf{3}$ & Marital Status & Single & 49.03 & 27.42 \\
& & Married & 50.97 & 72.58 \\
\hline $\mathbf{4}$ & Education Level & Undergraduate & 30.67 & - \\
& & Graduate & 51.46 & 27.42 \\
& & Post Graduate and above & 17.87 & 72.58 \\
\hline $\mathbf{5}$ & Frequency of Internet & Less than 4 hours/week & 13.77 & - \\
& Use & 4-8 hours/week & 25.61 & 33.87 \\
& & 8-12 hours/week & 40.34 & 34.52 \\
& & More than 12 hours/week & 20.28 & 31.61 \\
\hline
\end{tabular}

\section{Analysis and results}

The reliability of the data is checked by calculating Cronbach- $\alpha$ value which are found 0.966 and 0.954 for questionnaire- 1 and 2 respectively. The calculated value is in the quite acceptable range (>0.7) (Nunnally, 1978). Further to this Kaiser Mayer Oklin statistics is calculated for checking the sampling adequacy, the calculated values are 0.688 and $0.696(>0.5)$ which is found quite suitable for carrying out exploratory factor analysis. Exploratory factor analysis was carried out and based on the rotated component matrix a total of 5 factors were extracted from each perspective along with 17 and 16 indicators contributing towards $62.15 \%$ and $64.68 \%$ of the variance from the learners and faculty member perspectives respectively. Based on these factors the authors have proposed the e-learning quality constructs. The extracted factors along with their indicators are shown in Table 2 and 3.

Course Content (COC): This factor is inclusive of dimensions namely number of courses offered, syllabus coverage, availability of library resources to access the course related material and the perceived usefulness of the overall course content. 
Design Structure (DES): This factor is inclusive of two way interaction of the e-learning website, updated technological infrastructure, ease in navigating the website and user friendliness of e-learning website \& privacy and security of information provided by the students.

Table 2

Exploratory factor analysis (rotated component matrix), faculty perspective

\begin{tabular}{|c|c|c|c|c|c|}
\hline & \multicolumn{5}{|c|}{ Component } \\
\hline & $\mathrm{COC}$ & DES & TRA & TKH & ENG \\
\hline COC1: Number of courses offered & .603 & & & & \\
\hline COC2: Syllabus coverage & .520 & & & & \\
\hline COC3: Availability of library resources & .648 & & & & \\
\hline COC4: Perceived use fulness & .710 & & & & \\
\hline DES1: Interactivity & & .758 & & & \\
\hline DES2: Updated technological infrastructure & & .694 & & & \\
\hline $\begin{array}{l}\text { DES3: Ease of navigation and user friendliness of } \\
\text { e-learning website }\end{array}$ & & .653 & & & \\
\hline DES4: Customized interface & & .573 & & & \\
\hline DES5: Privacy and security of information & & .546 & & & \\
\hline $\begin{array}{l}\text { TRA1: Evaluation process to improve } \\
\text { teaching/learning process }\end{array}$ & & & .706 & & \\
\hline TRA2: Proper feedback mechanism & & & .755 & & \\
\hline TRA3: Proper guidelines for evaluation process & & & .582 & & \\
\hline TKH1: Technical assistance in course development & & & & .780 & \\
\hline TKH2: Availability of peer in mentoring resources & & & & .716 & \\
\hline ENG1: Minimum amount of time per week & & & & & .736 \\
\hline $\begin{array}{l}\text { ENG2: Self-assess the required motivation and } \\
\text { commitment }\end{array}$ & & & & & .627 \\
\hline
\end{tabular}

Table 3

Exploratory factor analysis (rotated component matrix), learner perspective

\begin{tabular}{|c|c|c|c|c|c|}
\hline & \multicolumn{5}{|c|}{ Component } \\
\hline & $\mathrm{COC}$ & DES & COL & INA & VAA \\
\hline COC1: Number of courses offered & .555 & & & & \\
\hline COC2: Syllabus coverage & .828 & & & & \\
\hline COC3: Availability of library resources & .696 & & & & \\
\hline COC4: Perceived use fulness & .762 & & & & \\
\hline DES1: Interactivity & & .581 & & & \\
\hline DES2: Updated technological infrastructure & & .743 & & & \\
\hline $\begin{array}{l}\text { DES3: Ease of navigation and user friendliness of } \\
\text { e-learning website }\end{array}$ & & .669 & & & \\
\hline DES4: Privacy and security of information & & .503 & & & \\
\hline $\begin{array}{l}\text { COL1: Facilitation of students interaction with } \\
\text { faculty }\end{array}$ & & & .571 & & \\
\hline $\begin{array}{l}\text { COL2: Facilitation of students interaction with } \\
\text { other students }\end{array}$ & & & .523 & & \\
\hline COL3: Tie-ups with other e-learning websites & & & .741 & & \\
\hline $\begin{array}{l}\text { COL4: Industry experts and institute collaboration } \\
\text { in curriculum design }\end{array}$ & & & .511 & & \\
\hline $\begin{array}{l}\text { INA1: Course approved through a broad review } \\
\text { process }\end{array}$ & & & & .801 & \\
\hline INA2: Affiliation to industry & & & & .846 & \\
\hline VAA1: Provision of technical assistance & & & & & .680 \\
\hline VAA2: Provision for grading & & & & & .583 \\
\hline VAA3: Certification validity & & & & & .555 \\
\hline
\end{tabular}


Transparency in Assessment (TRA): This factor is inclusive of proper evaluation process to improve teaching/learning process and proper feedback mechanism so that the corrective actions can be taken as and when required.

Technical Know How (TKH): This factor is inclusive of technical assistance in course development and availability of peer mentoring resources for better exposure of students to the theoretical as well as practical aspects in their chosen area of expertise.

Engagement (ENG): This factor is inclusive of minimum amount of time per week devoted by students and self assessment of the required motivation and commitment for the particular course in which he is enrolled.

Collaboration (COL): This factor is inclusive of facilitation of student interaction with faculty as well as with other students, tie-ups with other e-learning websites for better access to academic resources such as reports, journals, and industry experts and institute collaboration in curriculum design so as to give the students theoretical as well as practical exposure.

Industry Acceptance (INA): This factor is inclusive of course approved through a broad review process and affiliation to industry so as make the students to choose the areas of expertise and accordingly get placed in different industries with those expertise requirements.

Value Addition (VAA): This factor is inclusive of Provision of technical assistance while uploading the course content and other relevant information, provision for grading the students according to their performance in different theoretical and practical aspects and the validity of the particular certification.

Table 4

Model fit indices (faculty perspective)

\begin{tabular}{lccccccccc}
\hline & \multicolumn{2}{c}{ Model Fit } & \multicolumn{2}{c}{ Absolute Measures } & \multicolumn{2}{c}{$\begin{array}{l}\text { Incremental } \\
\text { fit Measures }\end{array}$} & $\begin{array}{c}\text { Parsimonious } \\
\text { fit Measures }\end{array}$ & RMSEA \\
\cline { 2 - 9 } & $\chi^{2}$ & $\chi^{2} /$ df & RMR & GFI & AGFI & CFI & TLI & PCFI & \\
\hline $\begin{array}{l}\text { Measurement } \\
\text { Model 1 }\end{array}$ & 88.01 & 1.60 & 0.04 & 0.92 & 0.87 & 0.96 & 0.95 & 0.68 & 0.06 \\
\hline $\begin{array}{l}\text { Structural } \\
\text { Model 1 }\end{array}$ & 98.54 & 1.64 & 0.04 & 0.91 & 0.86 & 0.96 & 0.95 & 0.74 & 0.06 \\
\hline
\end{tabular}

Table 5

Model fit indices (learner perspective)

\begin{tabular}{|c|c|c|c|c|c|c|c|c|c|}
\hline & \multicolumn{2}{|c|}{ Model Fit } & \multicolumn{3}{|c|}{ Absolute Measures } & \multicolumn{2}{|c|}{$\begin{array}{l}\text { Incremental } \\
\text { fit Measures }\end{array}$} & \multirow{2}{*}{$\begin{array}{c}\text { Parsimonious } \\
\text { fit Measures }\end{array}$} & \multirow[t]{2}{*}{ RMSEA } \\
\hline & $\chi^{2}$ & $\chi^{2} / \mathrm{df}$ & RMR & GFI & AGFI & $\mathrm{CFI}$ & TLI & & \\
\hline $\begin{array}{l}\text { Measurement } \\
\text { Model } 2\end{array}$ & 201.87 & 2.52 & 0.04 & 0.89 & 0.84 & 0.92 & 0.89 & 0.69 & 0.07 \\
\hline $\begin{array}{l}\text { Structural } \\
\text { Model } 2\end{array}$ & 220.69 & 2.59 & 0.04 & 0.88 & 0.83 & 0.91 & 0.88 & 0.73 & 0.07 \\
\hline
\end{tabular}

In the first (Fig. 1) and second model (Fig. 2) e-learning quality is represented as a multi-dimensional construct explained by the five factors extracted through exploratory 
factor analysis from the faculty and learner perspectives respectively. These measurement models are verified through confirmatory factor analysis by using the second half of the data (Sample size: 155 and 207). In the measurement model from faculty perspective (Fig. 1) three dimensions namely DES4, DES5 and TRA3 were removed whereas in the measurement model from learner's perspective two dimensions DES4 and COL4 were removed because of inadequate standard loadings.

These measurement models (Fig. 1 and Fig. 2) and structural models (Fig. 3 and Fig. 4) are accepted because of accepted level of fit based on the calculated absolute measures, incremental fit measures and parsimonious fit measures. All the models (Table 4 and Table 5) indicated an acceptable model fit of the data (Anderson \& Gerbing, 1988). In addition to this all the indicators loaded significantly on the corresponding latent constructs. The values of the fit indices indicate a reasonable fit of the measurement model with the sample data (Byrne, 2001). In short, the structural models (Fig. 3 and Fig. 4) confirm the five-factor structure of e-learning quality from the learners and faculty perspectives respectively.

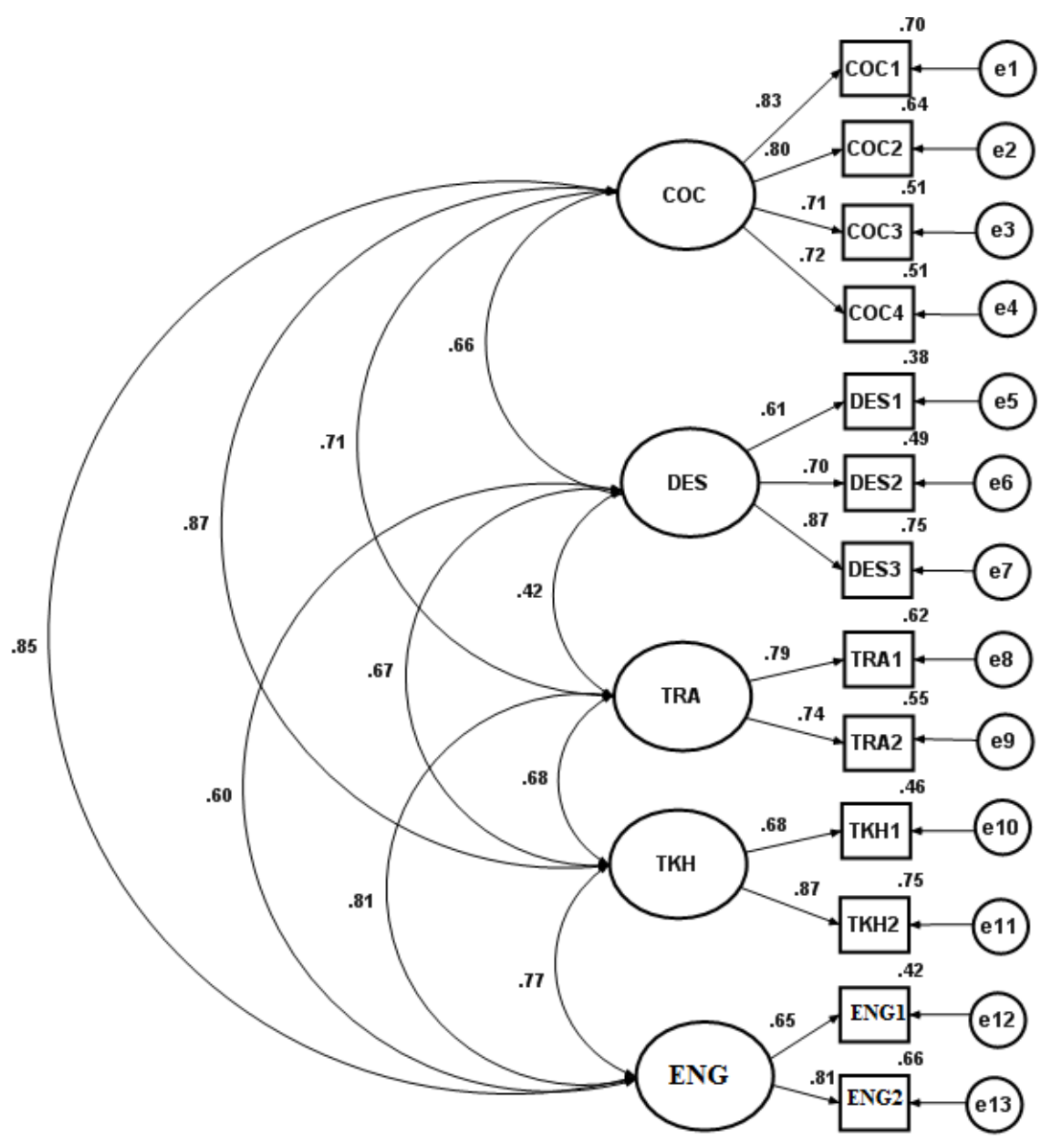

Fig. 1. Measurement model-1 (from faculty perspective) 


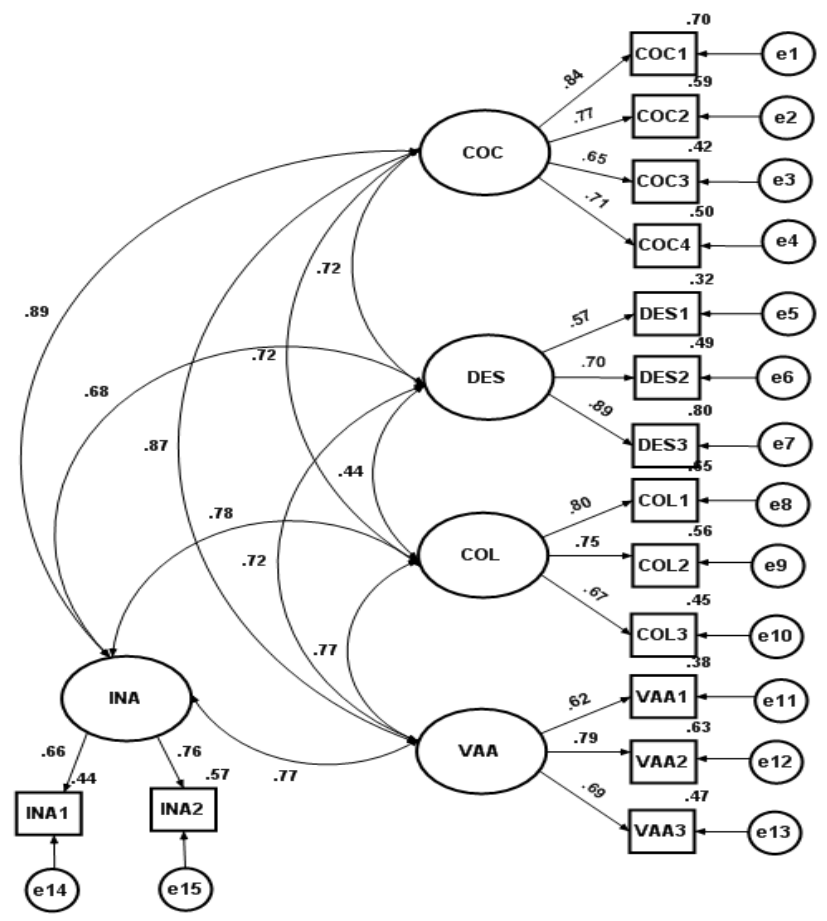

Fig. 2. Measurement model-2 (from learner perspective)

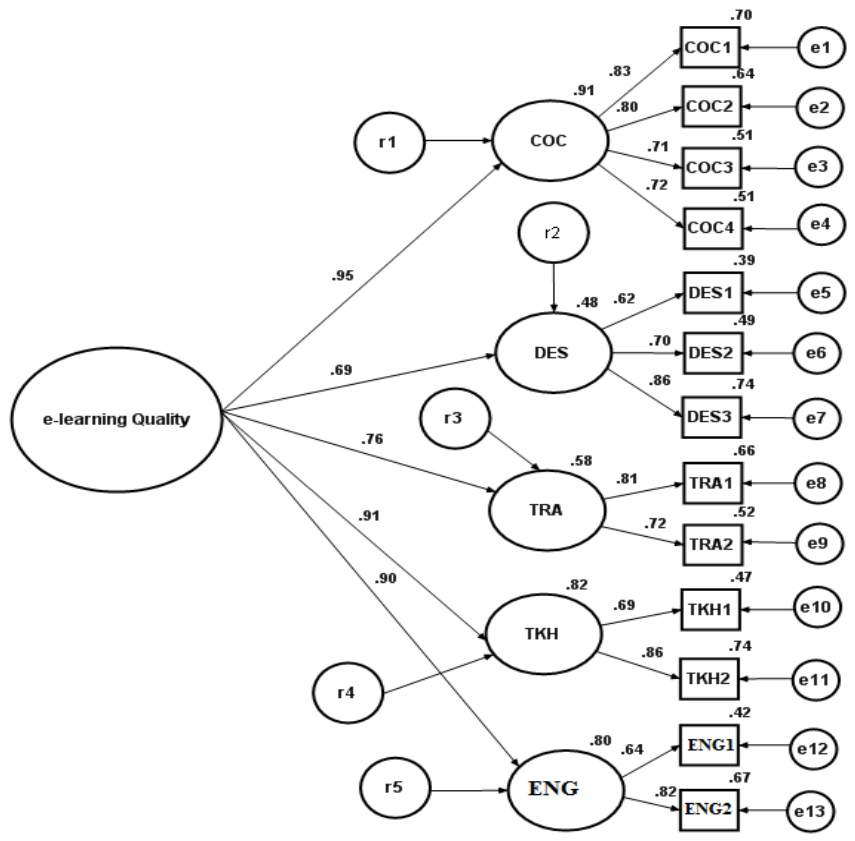

Fig. 3. Structural model-1 (from faculty perspective) 


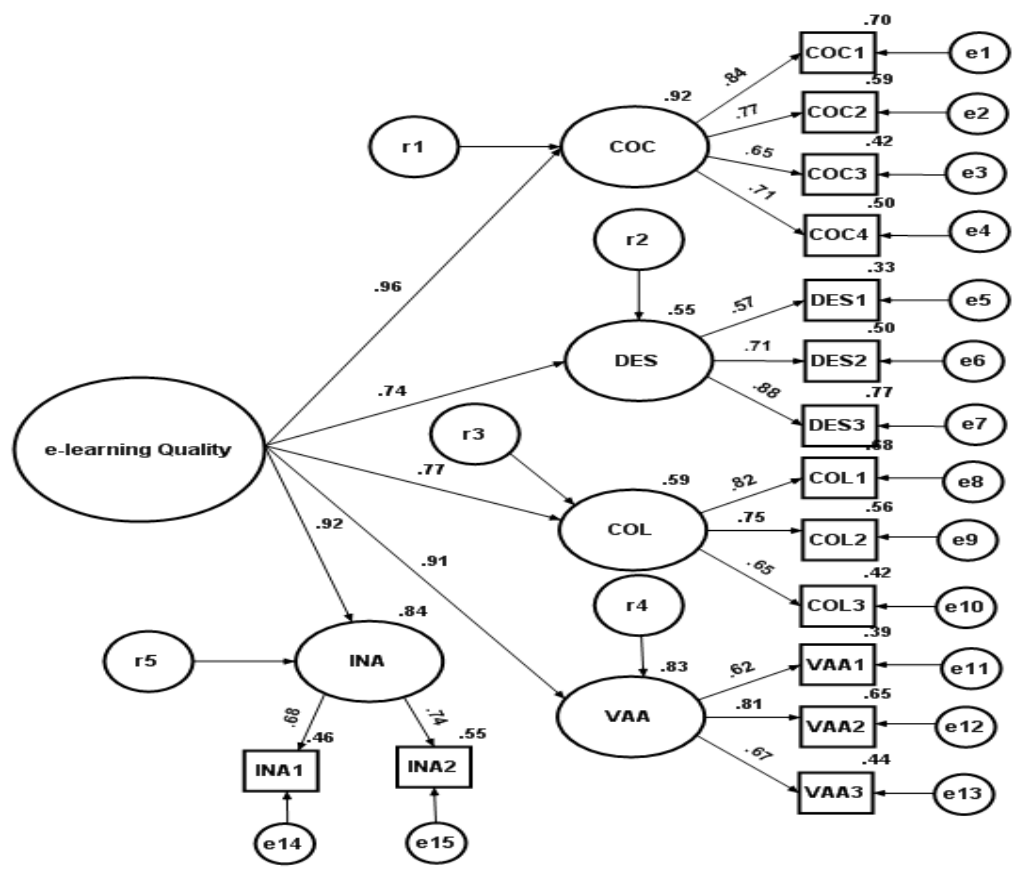

Fig. 4. Structural model-2 (from learner perspective)

Table 6

Composite reliability of the constructs (learner perspective)

\begin{tabular}{cc}
\hline Construct & Composite Reliability \\
\hline COC & 0.67 \\
\hline DES & 0.73 \\
\hline TRA & 0.81 \\
\hline TKH & 0.83 \\
\hline COL & 0.71 \\
\hline
\end{tabular}

Table 7

Composite reliability of the constructs (faculty perspective)

\begin{tabular}{cc}
\hline Construct & Composite Reliability \\
\hline COC & 0.67 \\
\hline DES & 0.73 \\
\hline TRA & 0.81 \\
\hline TKH & 0.83 \\
\hline ENG & 0.71 \\
\hline
\end{tabular}

The Table 6 and 7 shown above clearly indicates that the composite reliability of all the constructs is more than 0.6, which is quite acceptable (Carmines \& Zeller, 1988). Construct validity is established in this study by establishing the content validity, convergent validity and discriminant validity. Content validity is verified through existing literature and expert's interaction in the area of e-learning. Convergent validity is 
assessed by examining the average variance extracted and factor loadings (Fornell \& Larcker, 1981). All the indicators have shown significant loadings onto their respective latent constructs with values varying in between 0.62 to 0.84 . In addition, the average variance extracted (AVE) for each construct is greater than or equal to 0.50 , which further supports the convergent validity of the constructs. As suggested by (Fornell \& Larcker, 1981) the discriminant validity can be assessed by comparing the average variance extracted (AVE) with the corresponding inter-construct squared correlation estimates. AVE values for each latent construct were found more than the square of the inter-construct correlations. Thus, the measurement models (Fig. 1 and Fig. 2) reflect good construct validity and desirable psychometric properties (Ganguli \& Roy, 2011).

\section{Suggested planning and implementation strategy}

The quality models for e-learning are shown in Fig. 5 and Fig. 6. Based on these models we can formulate a planning and implementation strategy. The process-oriented model of e-learning is structured around three sequential non-linear phases:

Before: planning and analysis

During: design, prototype and production and

After: post-production and delivery

The above model is supported by an advanced information system used to organize, track, collect, and generate reports regarding QA changes and needed updates (Abdous, 2009). Each factor in the proposed models will play a significant role and strategy can be formulated based on these factors for effective planning and implementation of e-learning.

\section{Phase-1: "Before" Stage}

This stage primarily involves planning and analysis. Important decisions about salient features of the e-learning package need to be taken in this stage. First step should be to assess quality of package on number of courses offered, syllabus coverage, library resources and the perceived usefulness of the package to the learner. It would be critical to have accurate number of courses so as to cater the demand of the learner and also the current mix of courses. The syllabus coverage should be broad and should be designed in consultation with subject matter expert and the industry experts, so that it covers latest development in the subject course. Than accordingly the related e-library recourses have to be design so that the learners have correct study material to prepare for the course. The design structure of the e-learning website should be interactive and updated with the latest technology. Previously it would be enough to have textual and graphical material to explain the content, but now with enormous growth in technology, the heavy use of latest technologies like audio, video, and flash etc is highly recommended. The earlier basics like easy navigation and user-friendliness are still important factors in designing the elearning website. In the planning and analysis phase, existing service provider's technology must be researched and best features should be incorporated in the e-learning package.

\section{Phase-2: "During" Stage}

In this stage the service provider would be required to develop a prototype and start production (i.e. test launch) of the e-learning package. The test launch will give the service provider much valuable and needed feedback of the actual user, in terms of what 
features are missing and additional quality improvement measures should be taken. Primarily this stage requires maximum focus and efforts. If any sub-quality features is found should be improved otherwise it effect will get many folds in the next, postproduction stage. The factors like, interaction facility between, faculty and learner or among learners themselves, Affiliation to Industry, Certification validity and Technical assistance should be used to assess the quality of the package.

\section{Phase-3: “After" Stage}

In the third stage the focus would be to ensure timely delivery and bug free (i.e. quality glitches). At this stage quality standards would be already in place as the service provider has done the quality assessment and benchmarking. Now only need of the hour would be quality assurance, i.e. to maintain the required level of quality and thus leading towards quality improvement. Both 15 point scale (as per learner's perspective) and 13-point scale (as per faculty's perspective) should be used to assess the current quality level of the e-learning package and to identify improvement area.

\section{Conclusion}

The penetration of online learning is increasing day by day. Learners perceive the online learning environment as quite valuable due to the reduction of time, effort and money in getting timely and updated information. As learners react in the online encounters differently than in the traditional offline encounters so organizations engaged in providing online education should clearly aware about the important factors that are contributing to learners satisfaction which will finally help the organization in increasing the effectiveness of the e-learning environment. Increasing the effectiveness of these variables will result into greater customer's satisfaction. This in turn will lead to positive word of mouth and increased rate of retention and will help in building a loyal learners base. This research study has developed two measurement scales based on five factors from perception of both learner and faulty for measuring service quality of e-learning service providers. From learner's point of view the major factors are: Course Content, Design Structure, Collaboration, Industry Acceptance and Value Addition. From faculty point of view five factors are course content, design structure, transparency in assessment, technical know-how and engagement (from student). The following models (Fig. 5 and Fig. 6) are proposed:

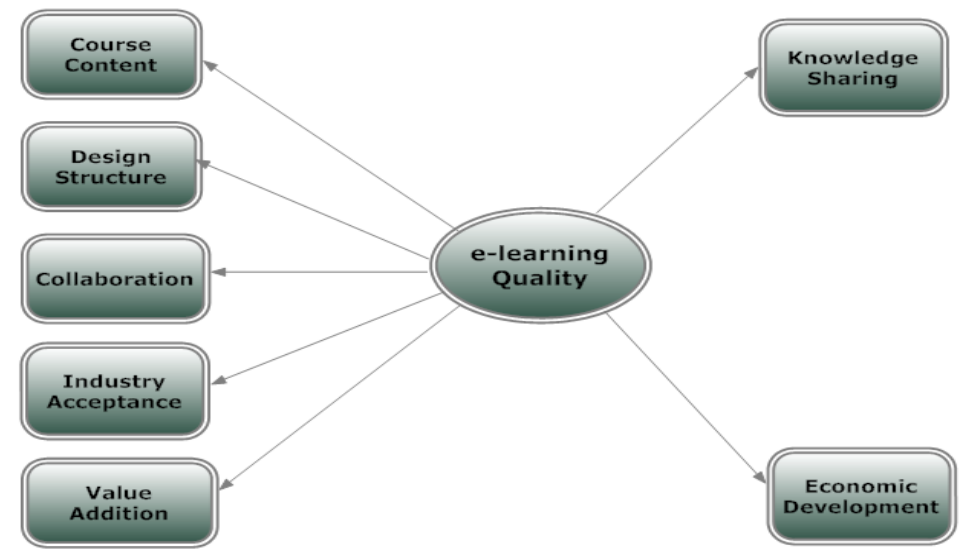

Fig. 5. From learner perspective 


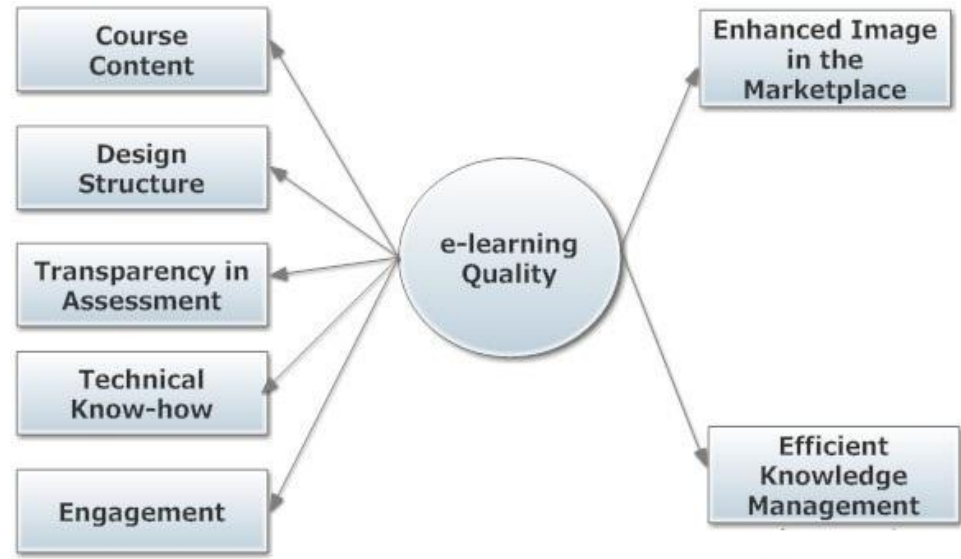

Fig. 6. From faculty perspective

This paper contributes to the existing literature by finding the factors that learners as well as faculty perceive as important while interacting with online learning websites. Organization should give due attention to these factors for creating an effective learning environment online and to make effective strategies accordingly. The sample sizes itself were relatively small, which is one of the limitations of this study. Large and more diversified samples can be taken for the further enhancement as well as validation of this research work. The applicability, validation and generalizability of the proposed scale can be done by replicating this study in e-learning aspects of other geographical segments at a national level.

\section{References}

Aagja, J. P., \& Garg, R. (2010). Measuring perceived service quality for public hospitals (PubHosQual) in the Indian context. International Journal of Pharmaceutical and Healthcare Marketing, 4(1), 60-83.

Abdous, M. (2009). e-Learning quality assurance: A process-oriented lifecycle model. Quality Assurance in Education, 17(3), 281-295.

Agariya, A. K., \& Singh, D. (2011a). CRM in banking: One size doesn't fit all. AIMA Journal of Management \& Research, 5(2), 1-25.

Agariya, A. K., \& Singh, D. (2011b). What really defines relationship marketing? A review of definitions, general and sector-specific defining constructs. Journal of Relationship Marketing, 10(4), 203-237.

Agariya, A. K., \& Singh, D. (2012). CRM index development and validation in Indian banking sector. International Journal of Customer Relationship Marketing and Management, 3(2), 10-32.

Anderson, J. C., \& Gerbing, D. W. (1988). Structural equation modeling in practice: A review and recommended two-step approach. Psychological Bulletin, 103, 411-423.

Anderson, T., \& Elloumi, F. (2004). Theory and practice of online learning. Abathasca University.

Boettcher, J. V., \& Conrad, R. M. (1999). Faculty guide for moving teaching and learning to the web. Mission Viejo, CA: League for innovation in the community College. Retrieved from www.league.org.

Bridgland, A., \& Goodacre, C. (2005). Benchmarking in higher education: A framework for benchmarking for quality improvement purposes. Council of Australian University 
Directors of Information Technology.

Byrne, B. M. (2001). Structural equation modeling with AMOS: Basic concepts, applications and programming. Lawrence Erlbaum Associates: Mahwah, NJ.

Carmines, E. G., \& Zeller, R. A. (1988). Reliability and validity assessment. Sage: Beverly Hills, CA.

Cashion, J., \& Palmieri, P. (2002). The secret is the teacher: The learner's view of online learning. Adelaide, NCVER.

Chapnick, S. (2000). Are you ready for e-learning. Learning Circuits: ASTD's Online Magazine All About E-Learning. Retrieved from http://www.astd.org/LC/2000/1100_chapnick.htm.

Chen, M. P. (2009). An evaluation of the ELNP e-learning quality assurance program: Perspectives of gap analysis and innovation diffusion. Educational Technology and Society, 12(1), 18-33.

Cho, E., \& Lee, S. (2004). Standardization factors in e-learning environment for quality enhancement. Journal of Educational Technology, 20(2), 3-32.

Chua, A., \& Lam, W. (2007). Quality assurance in online education: The universitas 21 global approach. British Journal of Educational Technology, 38(1), 133-152.

Doherty, G. (2008). On quality in education. Quality Assurance in Education, 16(3), 255-265.

Dolog, P., Henze, N., Nejdl, W., \& Sintek, M. (2004). Personalization in distributed elearning environments. Proceedings of the Thirteenth World Wide Web Conference, New York.

Dondi, C., Moretti, M., \& Nascimbeni, F. (2006). Quality of e-learning: Negotiating a strategy, implementing a policy. In U. D. Ehlers \& J.M. Pawlowski (Eds.), Handbook on Quality and Standardisation in E-learning. Springer: Berlin/ Heidelberg New York.

Ehlers, U. D. (2009). Web 2.0 - e-learning 2.0 - quality 2.0? Quality for new learning cultures. Quality Assurance in Education, 17(3), 296-314.

Finch, H. (2006). Comparison of the performance of varimax and promax rotations: Factor structure recovery for dichotomous items. Journal of Educational Measurement, 43, 29-52.

Fornell, C., \& Larcker, D. F. (1981). Evaluating structural equation models with unobservable variables and measure. Journal of Marketing Research, 18, 39-50.

Frydenberg, J. (2002). Quality standards in e-learning: A matrix of analysis. International Review of Research in Open and Distance Learning, 3(2), 1-15.

Ganguli, S., \& Roy, S. K. (2011). Generic technology-based service quality dimensions in banking: Impact on customer satisfaction and loyalty. International Journal of Bank Marketing, 29(2), 168-189.

Ge, X., Lubin, I. A., \& Zhang, K. (2010). An investigation of faculty's perceptions and experiences when transitioning to a new learning management system. Knowledge Management \& E-Learning: An International Journal, 2(4), 433-447.

Inglis, A. (2005). Quality improvement, quality assurance and benchmarking; comparing two frameworks for managing quality processes in open and distance learning. The International Review of Research in Open and Distance Learning, 6(1).

Inglis, A. (2008). Approaches to the validation of quality frameworks for e-learning. Quality Assurance in Education, 16(4), 347 -362.

Ireland, J., Correia, H., \& Griffin, T. (2009). Developing quality in e-learning: A framework in three parts. Quality Assurance in Education, 17(3), 145-150.

Jara, M., \& Meller, H. (2009). Factors affecting quality enhancement procedures for elearning courses. Quality Assurance in Education, 17(3), 220-232.

Jung, I. S. (2010). The dimensions of e-learning quality: From the learner's perspective. 
Educational Technology Research and Development, Advance online publication.

Lewis, R. C., \& Booms, B. H. (1983). The marketing aspects of service quality. In L. Berry, G. Shostack, \& G. Upah, (eds.), Emerging Perspectives on Services Marketing. Chicago: American Marketing.

Little, B., \& Duffy, J. (2011). Report: Geographic distribution of eLearn readers: A look at this site's changing community. Magzine eLearn, 2010(12), Article No. 1. Retrieved from http://elearnmag.acm.org/archive.cfm?aid=1920831.

McKinnon, K. R., Walker, S. H., \& Davis, D. (2000). Benchmarking: A manual for Australian universities. HED, DETYA, Canberra.

McLoughlin, C., \& Visser, T. (2003). Quality and e-learning: are there universal indicators. Sixteenth ODLAA Biennial Forum Conference Proceedings, Sustaining Quality Learning Environments, Canberra.

Mittal, M. (2008). Evaluating perceptions on effectiveness of e-learning programs in Indian banks: identifying areas for improvement. Development and learning in organizations, 22(2), 12-14.

Nagy, A. (2005). The Impact of E-Learning. In P. A. Bruck, A. Buchholz, Z., Karssen, \& A. Zerfass (Eds), E-content: Technologies and perspectives for the European market. Berlin: Springer-Verlag.

Naidu, S. (2006). e-Learning: A guidebook of principles, procedures and practices. New Delhi: Commonwealth Educational Media Centre for Asia.

Nakabayashi, K., Morimoto, Y., \& Hada, Y. (2010). Design and implementation of an extensible learner-adaptive environment. Knowledge Management \& E-Learning: An International Journal, 2(3), 246-259.

Newton, J. (2007). What is quality? In L. Bollaert, S. Brus, B. Curvale, L. Harvey, E. Helle, H.T. Jensen, J. Komljenovič, A. Orphanides \& A. Sursock (Eds.), Embedding quality culture in higher education. EUA Cases studies (pp. 14-20): EUA.

Nichols, M. (2008). e-Learning in context. E-premier series.

Nunnally, J. C. (1978). Psychometric theory (2nd ed.). New York: Tata McGraw-Hill.

Oliver, R. (2005). Quality assurance and e-learning: Blue skies and pragmatism. ALT-J, 13(3), 173-187.

Phipps, R., \& Merisotis, J. (2000). Quality on the line: Benchmarks for success in internet-based distance education. Washington, DC: The Institute for Higher Education Policy.

Quality Assurance Agency. (2004). Code of practice for the assurance of academic quality and standards in higher education. Section 2: collaborative provision of flexible and distributed learning (including e-learning), Quality Assurance Agency.

Segrave, S., Holt, D., \& Farmer, J. (2005). The power of the $6 / 3$ model for enhancing academic teacher's capacities for effective online teaching and learning: Benefits, initiatives and future directions. Australasian Journal of Educational Technology, 21(1), 118-135.

Silius, K., Miilumaki, T., Huhtamaki, J., Tebest, T., Merilainen, J., \& Pohjolainen, S. (2010). Students motivations for social media enhanced studying and learning. Knowledge Management \& E-Learning: An International Journal, 2(1), 51-67.

Sims, R., Dobbs, G., \& Hand, T. (2002). Enhancing quality in online learning: scaffolding design and planning through proactive evaluation. Distance Education, 23(2), 135-148.

Suddaby, G., \& Milne, J. (2008). Coordinated, collaborative and coherent: Developing and implementing e-learning guidelines within a national tertiary education system. Campus-Wide Information Systems, 25(2), 114-128.

Suna, P. C., Tsaib, R. J., Fingerc, L., Chend, Y. Y., \& Yeha, D. (2008). What drives a successful e-learning? An empirical investigation of the critical factors influencing learner satisfaction. Computers and Education, 50(4), 1183-1202. 
Tavangarian, D., Leypold, M., Nolting, K., Roser, M., \& Voigt, D. (2004). Is e-learning the solution for individual learning, Electronic Journal of E-Learning, 2(2), 273-280.

Western Cooperative for Educational Telecommunication (2002). Best practices for electronically offered degree and certificate programs. Retrieved from http://www.aaup.org/NR/rdonlyres/BBA85B72-20E9-4F62-B8B5CDFF03CD8A53/0/WICHEDOC.PDF.

Zhang, D., Zhao, J. L., Zhou, L., \& Nunamaker, Jr. J. F. (2004). Can e-learning replace classroom learning? Communications of the ACM, 47(5), 75-79.

Zikmund, W. G. (1991). Business research methods (3rd ed.). The Dryden Press: Chicago, IL. 